REPORTS OF MORPHOLOGY
Official Journal of the Scientific Society of Anatomists,
Histologists, Embryologists and Topographic Anatomists
of Ukraine
journal homepage: https://morphology-journal.com

\title{
Pathological changes on basis of ischemia with associated virus infection in mice brain
}

\section{Turchyna N.S. ${ }^{1}$, Savosko S.I. ${ }^{1}$, Ribalko S.L. ${ }^{2}$, Starosila D.B. ${ }^{2}$, Kolisnik D.I. ${ }^{1}$}

${ }^{1}$ National Medical University named after O.O. Bohomolets, Kyiv, Ukraine;

${ }^{2}$ State Enterprise "Institute of Epidemiology and Infectious Diseases named after. L.V. Gromashevsky National Academy of Science of Ukraine", Kyiv, Ukraine

\section{ARTICLE INFO}

Received: 28 September, 2018

Accepted: 15 November, 2018

UDC: $616.832-005.4-092: 616.9: 578]$

\section{CORRESPONDING AUTHOR}

e-mail: ntlturchina12@ukr.net Turchyna N.S.
The global literature constantly receives new data showing the infectious pathogens as factors for development of atherosclerosis and acute cerebrovascular pathology, and the data showing the predictors of pathology of the heart-vessels as markers of inflammation. The results of research about the connection between the infectious agents and atherosclerosis are ambiguous, and the attempts to prove such connection have encouraged the experiments where the infectious agents with atherogenesis are modeled in animals. The connection of this data with ischemic lesion of brain is not properly explored, but certain experimental research show progressive degeneration in brain hemorrhage in mice with herpes virus 1 (HSV1) due to the post-stroke immunosuppression and reactivation of the infectious agent. The aim of this work is to explore experimentally the possible connection between the herpetic infection and the ischemic lesion to the cortex of mice. To achieve this goal we formed 5 groups of experimental animals (mice) for investigation into the possibility of connection between herpes infection and ischemiazaition of brain: $1^{\text {st }}$ group $(n=52)$ - with cholesterol diet; $2^{\text {nd }}$ group ( $\left.n=23\right)$ - with HSV1; $3^{d}$ group $(n=30)$ - with unilateral occlusion of the common carotid artery; $4^{\text {th }}$ group $(n=10)$ - with HSV1 and occlusion of the common carotid artery; $5^{\text {th }}$ group $(n=6)$ - with cholesterol diet, HSV1, occlusion of the common carotid artery. The microscopic slides evaluated changes morphometrically in the density of the neurons of the neocortex in the ocular of parietal temporal fields of the brain and the hippocampus. The results were processed statistically with Origin Lab 8.0. A probable increase in structural changes was identified in group 5 (with three pathological factors respectively) of the combined model compared to models without association and/or with several pathological signs from the groups 1-4 (1, 2, 3, 4). Comparison of the results between the $1-4^{\text {th }}$ and $5^{\text {th }}$ groups showed a significant increase in the relative number of neurons with cytopathological signs (hemochromatosis, deformation of the perikaryon, karyopyknosis), which may testify in favor of a sufficiently rapid lesion of the pyramidal neocortex neurons influenced by two or more pathological signs. The reduction in the density of pyramidal neurons in the temporal and/or temporal cortex in the combined model with ischemiazaition and viral association in was had greater probability compared to the models formed with only one risk factor. The revealed increase in the degree of neocortex induction during brain cerebral ischemia in mice with herpes infection is an evidence of possible connection between the two. Keywords: brain, mice, ischemia, viral infection.

\section{Introduction}

In the world literature, there is a growing number of data indicating some infectious agents, as factors in the development of atherosclerosis (AS) and acute cerebrovascular pathology (ACP), and about the predictors of acute cardiovascular disease as markers of inflammation. The ambiguous results of the research on the relationship between infection and atherosclerosis and attempts to prove the existence of such an association have led to attempts to simulate infection-associated atherogenesis in animals [4, $10,11,21]$. In the experimental work M.V. Avdeyev and colleagues in 2012 give data on the impact of various infectious agents on the development and progression of 
atherosclerosis [3]. A study by R. Sorrentino et al. (2015) demonstrated the possibility of inducing AS by infection C. pneumoniae in the absence of hypercholesterolemia [25, 26].

One of the possible causes of damage to the arterial wall and, as a consequence, the development of atherogenesis, is herpesviruses [17, 30]. The role of herpes viruses, as etiologic factors of AS, has been thoroughly investigated in recent years and is now supported by numerous data. There is growing evidence of the involvement of viruses Herpes viridae (Herpes simplex virus (HSV) 1 and type 2, type 3 (VZV), Epstein-Barr virus (EBV), cytomegalovirus (CMV) in the processes of damage and maintenance of endothelium inflammation, accumulation cholesterol, changes in the coagulation properties of the endothelium, increased thrombogenesis [5, 18, 25]. HSV types 1 and 2 were found in the aorta and carotid artery of patients with AS of vessels [7, 20,24]. In the in vitro study, it was found that HSV type 1 enhances absorption of low density lipoproteins by endothelial cells, and saturated cholesterol esters and triglycerides in unbranched cells [6, 16]. An experiments have shown that the Marek virus (herpes virus of birds) causes atherosclerotic changes in chickens [10]. D.G. Alber et al. (2000) demonstrated that infection with murine $y$-herpesvirus-68 leads to AS in apoE-/-mice [1]. D.G. Alber et al. (2002) conducted another study that proves that the development of AS is the result of a specific manifestation of a specific viral infection rather than a systemic immune response to the presence of any HSV [2]. Thus, the literature describes the results of only a few studies devoted to the study of the relationship between the persistence of herpes viruses and the development of atherogenesis, but some contradictory data question the participation of the viral factor directly in its launch, emphasizing the complicity of infectious agents in the already initiated inflammation of the vascular wall, damage to the endothelium. The association of these changes with ischemic brain damage is even less researched, although some experimental studies have shown progressive degeneration in the brain of mice infected with HSV type 1, due to post-stroke immunosuppression and reactivation of the infectious agent [14, 22]. Understanding of the problem of herpes-associated atherosclerosis is facilitated by more recent experimental studies conducted.

The purpose of the work is to investigate in the experiment the possible connection between herpetic infection and ischemic damage to the cerebral cortex of mice.

\section{Materials and methods}

To investigate the possible relationship between the development of herpetic infection and cerebral ischemia, we have formed 5 groups of experimental animals (mice): 1 group $(n=52)$, diet using cholesterol, group $2(n=23)$ with HSV1 infection, group $3(n=30)$ with unilateral occlusion of the common carotid artery (OCCA), group $4(n=10)$ with HSV1 and OCCA infections, group $5(n=6)$ with HSV1 infection, cholesterol diet and OCCA. Additionally, an additional control group (intact animals) is included.

For reproduction of dyslipidemia and structural changes in blood vessels of animals, 1 group was kept on a "cholesterol diet" [28] on the basis of granulated feed that additionally contained animal and vegetable fats, cholesterol (the quantitative composition of the atherogenic diet per 100 $\mathrm{g}$ of the finished product included: heat treated animal fats (pork fat, butter) - 30-45 g; heat-treated vegetable fats (margarine) - 15-20 g; cholesterol - 1.5-2 g; calcium carbonate (CaCO3) - $1 \mathrm{~g}$; Mercazolil (1-methyl-2-mercaptoimidazole with the addition of potatoes starch, calcium stearate, refined sugar, talc) - $10 \mathrm{mg}$ (equivalent to a daily dose animals - $10 \mathrm{mg} / \mathrm{kg}$ ), which speeds up the metabolism and elimination of various hospital facilities; standard granulated feed - 32-52 g). Duration of the diet is 12 weeks.

Animals of the 2nd group infected HSV1 by the method described in the papers [14, 15, 22]. Manipulation with infected animals was carried out at the "Institute of Epidemiology and Infectious Diseases named after. L.V. Gromashevsky NAMS of Ukraine" (Head of the Laboratory of Experimental Chemotherapy of Viral Infections, MD, Prof. S.L. Rybalko). Animals of 1 and 2 groups were withdrawn from the experiment for 12 weeks by decapitation.

OCCA of animals from group 3 were done by imposing a ligature on the right common carotid artery (suture material $6 / 0$, Ethilon, J \& J) [19]. Surgical access to the artery was carried out under anesthesia (sodium thiopental, $40 \mathrm{mg} / \mathrm{kg}$, intraperitoneally, $2 \%$ solution of lidocaine, $0.3 \mathrm{ml}$ locally). The animals were withdrawn from the experiment on 1, 2, 3 and 4 days after OCCA by decapitation.

The brain of control and experimental animals was selected for histological examination. Brain samples were fixed in $10 \%$ neutral formalin solution. After dehydration in the rising concentrations of ethanol, dioxane and xylene, the material was poured into paraffin. Paraffin sections 4-6 microns thick colored with toluidine blue by Nissl, hematoxylin with eosin [23].

By micropreparations evaluated morphometrically changes in the density of the neurons of the neocortex of the parietal, temporal parts of the brain and the hippocampus. For this purpose, photographs of the same areas of the parietal, temporal, and hippocampal neocortex with the Olympus BX 51 microscope using the CarlZeiss software (AxioVision SE64 Rel.4.9.1) determined the total neuron density in the test area (microphotograph) and the number of damaged neurons (hyperchromatosis, deformation, neuronal edema).

Statistical processing of the results was carried out using the Origin Lab program, version 8.0. Normal distribution of results is estimated by the Kolmogorov-Smirnov criterion. Intergroup discrepancies between groups of samples were evaluated using nonparametric Kruskal-Wallis test (Kruskal-Wallis ANOVA). The results are presented as median (Me) and quartile intervals [Q1-Q3]. The difference was estimated to be significant at $p<0.05$. 


\section{Results}

The analysis of micropreparations of experimental groups allowed to isolate the main zones and anatomical brain structures that were damaged under the set models
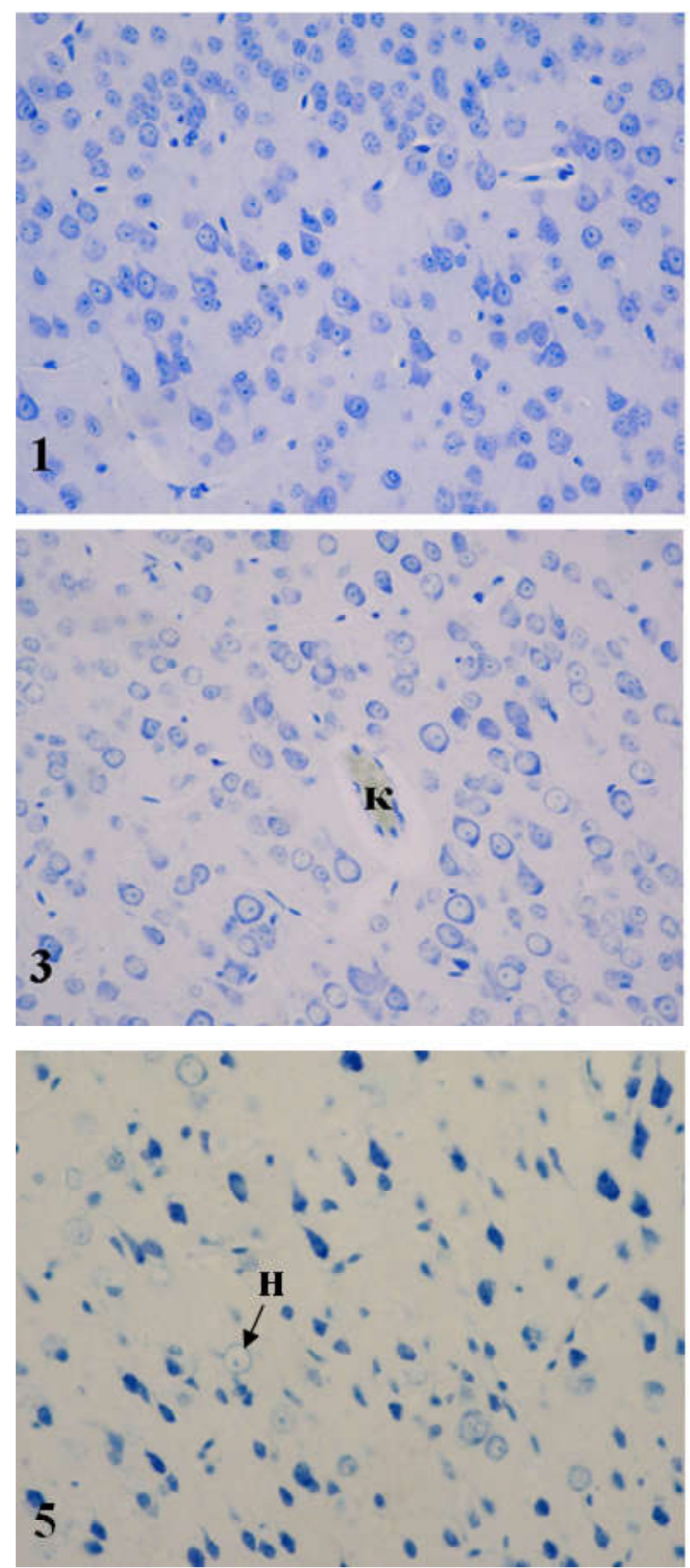

of the experiment. Changes were mainly found in the neocortex of parietal, temporal and hippocampal regions. Morphological signs of neurodegeneration and inflammatory reaction were established in the studied brain
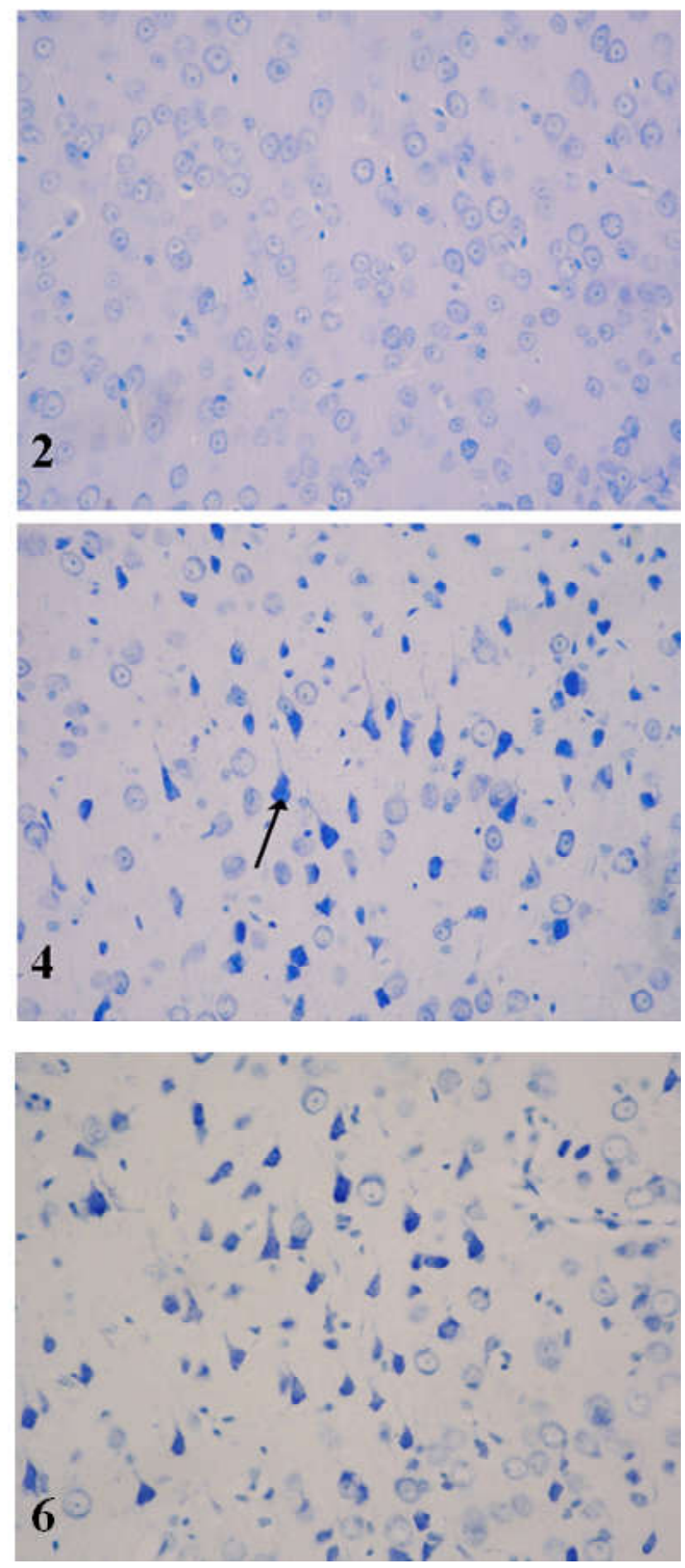

Fig. 1. Morphological manifestations of structural changes in the brain neurons in experimental group of mice. Degeneration of neurons in the parietal cortex of experimental groups. 1 - control; 2 - cholesterol diet, increasing the size of the nucleus of the neurons; 3 - OCCA for 1 day, intact the cerebral cortex; 4 - OCCA for 2 day, degenerative neurons $(\leftarrow) ; 5-\mathrm{HSV} 1+$ diet + OCCA for 1 day, degeneration and neuronal edema; 6 - HSV1 + diet + OCCA for 2 day, increase in the number of damaged neurons; $\mathrm{K}$ - capillary; $\mathrm{H}$ - swelling of the neuron. Toluidine blue. Lens 40, eyepiece 10. 
specimens. The manifestation of heterogeneous neuronal damage was hyperchromatosis and deformation of perikaryon and neurites, karyopyknosis or karyolysis. Microphotographs of degenerative changes in the cerebral cortex of the studied groups are shown in Figure 1. In order to assess the type of brain damage of the neurons, the main changes were divided into focal and diffuse. Accordingly, in the first case, deformed neurons were located in separate groups in the parietal and temporal neocortex, in separate sectors of the hippocampus. In the second case, the total loss of neurons and gliocytes was detected by continuous layers of the neocortex or multiple zones, which did not allow estimation of such changes as separate tricks of degeneration (damage) (Fig. 1).

Between the comparison groups, a difference was found between the degree of structural changes:

1 group with cholesterol diet $(n=52)$. In $22(42.5 \%)$ animals of the 52 who took the diet, isolated degenerative neurons were found at the level of parietal and/or temporal neocortex. In $11(50.0 \%)$ out of 22 samples, changes were assessed as diffuse, and in 10 (49.9\%) out of 22 as focal. In $11(21.1 \%)$ out of 52 animals, the morphological signs of the inflammatory reaction were observed: focal infiltration of monocytes and lymphocytes in $9(17.3 \%)$ of 52 specimens in the peritoneal mucosa of the trunk, large sulcus, parietal and/or temporal cortex, hippocampus, cortex vessels, corpus callosum and subcortical structures (lateral and dorsomedial zones of the thalamic region), choroidal arteries of the third ventricle (from 2 to 6 foci in the projection of the frontal section of the brain). In 4 samples $(7.6 \%)$ from 52 along the vessels, foci of infiltration of tissue basophils (from 3 to 16 cells), including degranulation, were recorded.

Group 2 with HSV1 infection (n=23). In 15 (69.5\%) animals from 23 who successfully transmitted infection with HSV, degeneration of neurons in the cerebral cortex and hippocampus was established. In 11 (73.3\%) of 15 samples, degeneration was assessed as diffuse, and in $4(26.6 \%)$ of 15 as a local (focal). In $12(52.1 \%)$ out of 23 animals, an inflammatory reaction was detected: focal infiltration of macrophages/microglyocytes around small caliber vessels (capillaries, arterioles, venules) in the cerebral cortex, corpus callosum, lateral areas of the thalamic zone.

3 group with OCCA $(n=30)$. The structural changes in the neocortex depended on the time elapsed since the time of the OCCA and assessed as diffusive and focal in the following way: 1 day $(n=15)-40.0 \%$ and $13.3 \%(46.7 \%$ unchanged); 2 day $(n=5)-60 \%$ and $40.0 \%$; 3 day $(n=5)$ $60 \%$ and $40 \% ; 4$ day $(n=5)-83.4 \%$ and $16.6 \%$. That is, neurodegenerative changes (karyopyknosis and hyperchromatosis of neurons or hydropic dystrophy) have progressed from focal to diffuse over time after OCCA. Morphological signs of inflammatory reaction were found in only $1(6.7 \%)$ of 15 specimens on 1 day.

Group 4 with HSV1 and OCCA $(\mathrm{n}=10)$. Like the OCCA group, diffuse and focal neocortex changes are estimated as follows: 1 day $(n=5)-60 \%$ and $20.0 \%(20.0 \%$ unchanged); 2 day $(n=5)-40 \%$ and $60.0 \%$. If for 1 day only 1 infiltration focus was registered, then for 2 day from 3 to 14 separate centers. The term of 3 and 4 days was not evaluated due to the $100 \%$ mortality of the animals.

Group 5 with HSV1 infection, cholesterol diet and OCCA $(n=6)$. In the neocortex, the focal changes dominated the diffuse ones: 1 day $(n=3)-33.3 \%$ and $66.7 \%$; 2 day $(n=3)-100 \%$ focal degeneration around monocyte/ lymphocyte infiltrates. For 2 day in all studied samples, 4 to 8 inflammation points were recorded. Experiment on days 3 and 4 also ended with 100\% lethality, which showed the severity of the somatic state of experimental animals. Table 1 and 2 summarize the results of quantitative evaluation of neuronal density in the parietal region of the neocortex. The probable increase in structural changes in group 5 (with three pathological factors) of the combined model is established in comparison with the models without combination and/or combination of several pathological signs of groups 1, 2, 3 and 4. Comparison of results between 1-4 and 5 groups indicates a statistically significant increase in the relative number of neurons with cytopathological features (hyperchromatosis, deformation of perikaryon, karyopyknosis), which correlates with more pathological signs, and is likely to result in more rapid damage to neocortical pyramidal neurons.

Table 1. Changes in the density of the pyramidal neurons of the III$\checkmark$ layers of the neocortex of the experimental groups (Me [Q1Q3]) in comparison with the control group.

\begin{tabular}{|c|c|c|}
\hline Group & $\begin{array}{l}\text { Neuronal density in } \\
\text { the test zone, abs. }\end{array}$ & $\begin{array}{c}\text { Relative number of } \\
\text { neurons with signs of } \\
\text { degeneration, } \%\end{array}$ \\
\hline Control & $195[185,7-205,7]$ & $3,3[1,9-3,9]$ \\
\hline HSV-I & $169[157,5-179,5]^{\star}$ & $8,98[7,3-12,9]^{*}$ \\
\hline Diet & $179[171,5-186,5] \#$ & $11,4[8,6-17,2] \#$ \\
\hline OCCA, 1 day & $182[170,2-192,7]$ & $12,9[7,3-17,1] \#$ \\
\hline OCCA, 2 day & $169,5[164,5-183]$ & $9,2[8,2-17,3] \#$ \\
\hline OCCA, 3 day & $164[154-179] \#^{\wedge}$ & $21,3[20,1-48,5] \#^{\star \wedge}$ \\
\hline OCCA, 4 day & $140[115,5-166,5] \#^{\star \wedge}$ & $39,1[22,7-59,2] \#^{\star \Lambda}$ \\
\hline $\begin{array}{c}\mathrm{HSV} 1+\mathrm{OCCA} \\
1 \text { day }\end{array}$ & $167[159,7-185,2]$ & $19,4[14,1-25,0]^{\star *}$ \\
\hline $\begin{array}{c}\mathrm{HSV} 1+\mathrm{OCCA} \\
2 \text { day }\end{array}$ & $171,5[164,5-180,7]$ & $14,7[9,0-28,0]$ \\
\hline $\begin{array}{l}\text { HSV1+ diet + } \\
\text { OCCA, } 1 \text { day }\end{array}$ & $157[145,5-165] \#^{*} \&$ & $26,4[24,8-31,5] \#^{\star \star} \&$ \\
\hline $\begin{array}{l}\text { HSV1+ diet }+ \\
\text { OCCA, } 2 \text { day }\end{array}$ & $137[129-163] \#^{*} \&$ & $43,0[39,5-54,6] \#^{*} \& " * *$ \\
\hline
\end{tabular}

Notes (here and thereafter): OCCA - occlusion of the common carotid artery; \# - $p<0,05$ compared to control; * $-p<0,05$ compared to 1 day; ${ }^{\wedge}-p<0,05$ compared to 2 day; ${ }^{* *}-p<0,05$ compared to HSV-I; \& - p<0,05 compared to OCCA; "- $p<0,05$ compared to HSV1 + OCCA; ! - p<0,05 compared with diffuse degeneration, the same observation period; according to Kruskal-Wallis criterion (Kruskal-Wallis ANOVA). 
Table 2. Dependence of density of pyramidal neurons of III-V layers on the nature of changes and development of violations of experimental groups (Me [Q1-Q3]) in comparison with the control group.

\begin{tabular}{|c|c|c|}
\hline Group & $\begin{array}{l}\text { Neuronal density in } \\
\text { the test zone, abs. }\end{array}$ & $\begin{array}{l}\text { Relative number of } \\
\text { neurons with signs of } \\
\text { degeneration, } \%\end{array}$ \\
\hline Control & $195[185,7-205,7]$ & $3,3[1,9-3,9]$ \\
\hline \multicolumn{3}{|c|}{ Diffuse degeneration of neuronal changes } \\
\hline HSV1 & $169[157,5-176,5]$ & $10,9[8,23-13,1]$ \\
\hline Diet & $184[179-187]$ & $10,7[8,6-17,8] \#$ \\
\hline OCCA, 1 day & $174[162,5-179,5]$ & $16,3[11,2-20,9] \#$ \\
\hline OCCA, 2 day & $176[166,2-185]$ & $9,2[7,5-13,6] \#$ \\
\hline OCCA, 3 day & $164[148-176,5]$ & $44,1[19,1-49,2] \#^{\wedge}$ \\
\hline OCCA, 4 day & $137,5[112,7-170,2]$ & $41,2[24,8-64,3] \#^{\wedge}$ \\
\hline HSV1+ OCCA, 1 day & 172 [159-185] & $16,7[6,3-30,8] \#$ \\
\hline HSV1+ OCCA, 2 day & 178 [165-189] & $13,4[4,2-20,6] \#$ \\
\hline $\begin{array}{c}\mathrm{HSV} 1+\text { diet }+\mathrm{OCCA} \\
1 \text { day }\end{array}$ & $165[149-170]$ & $26,4[24,8-28,1] \# \&$ \\
\hline $\begin{array}{c}\text { HSV1+ diet + OCCA } \\
2 \text { day }\end{array}$ & & - \\
\hline \multicolumn{3}{|c|}{ Focal degeneration of neurons } \\
\hline HSV1 & $154,5[139-199,2]$ & $7,9[3,3-12,5] \#$ \\
\hline Diet & $176[169-184]$ & $13,6[10,1-19,2] \#$ \\
\hline OCCA, 1 day & $184[182-196] !$ & $13,1[8,1-17,3] \#$ \\
\hline OCCA, 2 day & 169 [163-186] & $19,3[8,5-24,2] \#$ \\
\hline OCCA, 3 day & 179 [164-179] & $20,1[20,1-21,7] \#$ \\
\hline OCCA, 4 day & $162[158-165]$ & $24,0[19,7-27,2] \#$ \\
\hline HSV1+ OCCA, 1 day & 162 [160-186] & $21,4[17,2-23,1] \#$ \\
\hline HSV1+ OCCA, 2 day & $169[163-174]$ & $16,0[10,6-50,3] \#$ \\
\hline $\begin{array}{c}\text { HSV1+ diet + OCCA } \\
1 \text { day }\end{array}$ & $150[142-157]$ & $28,6[25,3-34,5] \# ! \& "$ \\
\hline $\begin{array}{c}\text { HSV1+ diet + OCCA } \\
2 \text { day }\end{array}$ & 137 [129-163] & $43,0[39,5-54,6] \# ! \& "$ \\
\hline
\end{tabular}

\section{Discussion}

Thus, step-by-step experiments allow us to investigate the relationship between the presence of neuroinfection and the level of ischemic brain damage. An analysis of the mortality of animals and the results of histological studies allowed us to conclude that the fastest development of structural changes in the cerebral cortex of the 5th mice group, in which the conditions of the experiment immediately coincided 3 pathological factors: cholesterol diet, neuroinfection and ischemic lesion of the brain.

As indicated in the literature, cerebral ischemia in onesided OCCA in mice and rats causes damage to the white matter of the brain, mild motor disorders and memory impairment [27, 31], which is a good model for the study of focal hypoxia [14], vascular dementia and neurodegeneration [29]. Changing the diet (cholesterol diet) increases the size of the area of brain damage of mice after a one-sided OCCA [18]. Bilateral OCCA initially causes ischemic tolerance, and later significant dystrophic and necrotic changes in the anatomical brain structures [28].

In our experiment, it has been shown that the addition of dietary fat in the diet of mice causes an increase in proteolytic enzymes in vessels, in particular, MMP-9, which worsens the state of both macro- and microvessels of the cerebral cortex. Ischemia of the brain increases the edema of the brain, the volume of ischemic damage worsens neurological functions in experimental animals [9].

The deterioration of the biochemical processes of the brain after the occlusion of the middle cerebral artery in animals with a fat diet is attributed to disorders of the metabolism carried out by the liver cells [20]. The views on these changes are controversial. Some authors believe that an increase in the level of ketone bodies (acetoacetate and $\beta$-hydroxybutyrate) has an effect on the restoration of the energy balance of cells, and may also have a neuroprotective effect [20]. According to another version, high levels of ketone bodies are toxic to the brain, and leads to ketoacidosis [12, 13]. Locomotor activity and changes in biochemical parameters, in particular, TBCactive products, deteriorate in the modeling of brain ischemia on the background of a fatty diet. Conducted clinical studies prove that there is a development of dysmetabolic processes with long-term use of fatty diet, which affects the increase of the area of diffuse changes in damaged brain in the case of ischemia. In his own studies, a fat diet was used to study vascular changes, and a deterioration was observed [3]. It was found that on the background of fatty diet, ultrastructural endothelial and nonstratified cell disorders develop, lipid deposits in vessels are accumulated, which may be considered as an initiatory stage of atherogenesis. OCCA in animals of the 3rd group was considered to a greater extent as a pathogenetically relevant model of brain ischemia. Therefore, the next stage of the experiments was the transfer of infected animals that successfully transmitted infections with neuroinfection, on a fat diet. The acute exacerbation of the inflammatory process and neurodegeneration after OCCA in animals fed fatty foods that successfully transmitted HSV1 contamination was confirmed by the fact that brain ischemia is probable under these conditions, which are factors in the weakening of the body. The increase in the area of the centers of the inflammatory process is due to the reactivation of HSV1, which was found in earlier experiments $[8,14,15,31]$. The results of the conducted studies allow to broaden the idea of the influence of the viral association on the pathogenesis of ischemic stroke and to understand the role of the vascular wall in these changes.

Prospects for the continuation of experimental studies in the study of the association of viral infection and the development of ischemic stroke, as well as morphological changes in the heart and aorta in the development of the 
infectious process and its correction is obvious. The prospect of further development is the study of morphological changes in the heart and aorta in the development of the infectious process and its correction.

\section{Conclusions}

1. OCCA caused a statistically significant decrease in the density of pyramidal neurons in the parietal and/or temporal cortex of the brain for 3-4 days, as opposed to the first 2 days, and is accompanied by morphological manifestations of neurodegeneration.

2. There is a tendency of increasing the damage to the cerebral cortex in up to 2 days after OCCA in infected animals

\section{References}

[1] Alber, D. G., Powell, K. L., Vallance, P., Goodwin, D. A., \& Grahame-Clarke, C. (2000). Herpesvirus infection accelerates atherosclerosis in the apolipoprotein E-deficient mouse. Circulation, 102(7), 779-785.

[2] AI-Ghamdi, A. (2012). Role of herpes simplex virus-1, cytomegalovirus and Epstein-Barr virus in atherosclerosis. Pak. J. Pharm. Sci., 25(1), 89-97.

[3] Avdeeva, M. V., Samoylova, I. G., \& Scheglov, D. S. (2012). Pathogenetics aspects of relationship mouth infectious diseases with development and progression atherosclerosis and possibility for their integrated prevention. Journal Infectology, 4(3), 30-34. https://doi.org/10.22625/2072-67322012-4-3-30-34

[4] Borisov, A. V., Semak, A. E., \& Churakov, A. V. (2011). Role of infection in pathogenesis of cerebral atherosclerosis and infarct of brain. Military Medicine, 4, 99-105.

[5] Chirathaworn, C., Pongpanich, A., \& Poovorawan, Y. (2004). Herpes simplex virus 1 induced LOX-1 expression in an endothelial cell line, ECV 304. Viral Immunology, 17(2), 308314.

[6] Chiu, B., Virra, E., Tucker, W., \& Fong, I. W. (1997). Chlamydia pneumoniae, cytomegalovirus, and herpes simplex virus in atherosclerosis of the carotid artery. Circulation, 96(7), 21442148.

[7] Deng, J., Zhang, J., Feng, C., Xiong, L., \& Zuo, Z. (2014). Critical role of matrix metalloprotease- 9 in chronic high fat diet-induced cerebral vascular remodelling and increase of ischaemic brain injury in mice†. Cardiovascular research, 103(4), 473-84.

[8] Edvinsson, M., Tallkvist, J., Nystram-Rosander, C., \& llback N.G. (2017). Cholesterol uptake in the mouse aorta increases during Chlamydia pneumoniae infection. Pathog. Dis, 75(1), 1-8. doi: 10.1093/femspd/ftx004.

[9] Fabricant, C. G., Fabricant, J., Litrenta, M. M., \& Minick, C. R. (1978). Virus-induced atherosclerosis. J. Exp. Med, 148(1), 335-340.

[10] Febbraio, M., \& Silverstein, R. L. (2007). CD36: implications in cardiovascular disease. The international journal of biochemistry \& cell biology, 39(11), 2012-2030. doi:10.1016/ j.biocel.2007.03.012

[11] Fedorovich, S. V., Voronina, P. P., \& Waseem, T. V. (2018). Ketogenic diet versus ketoacidosis: what determines the influence of ketone bodies on neurons?. Neural regeneration research, 13(12), 2060-2063. doi:10.4103/1673-5374.241442

[12] Flint, J.J., Blackband, S.J., \& Thelwall, P.E. Unilateral common carotid artery occlusion: a transient ischemia model well suited to MR studies. Proc. Intl. Soc. Mag. Reson. Med, 14, 1457. with HSV1, and $100 \%$ mortality on the 3 day, indicating a relationship between the degree of ischemic damage to neuroinfection.

3. Reduction in the density of pyramidal neurons in the parietal and/or temporal cortex of the brain in a combined model with ischemia and viral association in the experiment was significantly greater than those in which only one risk factor was used.

4. The detected increase in the degree of damage to the neocortex in brain ischemia in mice with herpetic infection is evidence of a possible association between them, which is due to an increase in focal inflammation and progressive neurodegeneration.

[13] Gumenyuk, A., Motorna, N., Rybalko, S., Savosko, S., Sokurenko, L., Starosyla, D. ... Chaikovsky, Yu. (2017). Development of herpetic infection associated with stroke and its correction with acyclovir. Curr Issues Pharm Med Sci, 30(1), 20-23.

[14] Gumenyuk, A. V., Motorna, N. V., Rybalko, S. L., Savosko, S. I., Sokurenko, L. M., \& Chaikovsky, Yu. B. (2016). Mutual influence of herpes virus infection activation and cerebral circulation impairment on the state of brain cells. Biopolym. Cell, 32, 2: 126-130.

[15] Hajjar, D. P., Pomerantz, K. B., Falcone, D. J., Weksler, B. B., \& Grant, A. J. (1987). Herpes simplex virus infection in human arterial cells. Implications in arteriosclerosis. The Journal of clinical investigation, 80(5), 1317-1321. doi:10.1172/ JCl113208

[16] Jalal, F. Y., Yang, Y., Thompson, J., Lopez, A. C., \& Rosenberg, G. A. (2012). Myelin loss associated with neuroinflammation in hypertensive rats. Stroke, 43(4), 1115-1122. doi:10.1161/ STROKEAHA.111.643080

[17] Key, N. S., Vercellotti, G. M., Winkelmann, J. C., Moldow, C. F., Goodman, J. L., Esmon, N. L., ... Jacob, H. S. (1990). Infection of vascular endothelial cells with herpes simplex virus enhances tissue factor activity and reduces thrombomodulin expression. Proceedings of the National Academy of Sciences of the United States of America, 87(18), 7095-7099.

[18] Koch, K., Berressem, D., Konietzka, J., Thinnes, A., Eckert, G. P., \& Klein, J. (2017). Hepatic Ketogenesis Induced by Middle Cerebral Artery Occlusion in Mice. Journal of the American Heart Association, 6(4), e005556.

[19] Kotronias, D., \& Kapranos, N. (2005). Herpes simplex virus as a determinant risk factor for coronary artery atherosclerosis and myocardial infarction. In Vivo, 19(2), 351-358.

[20] Lucas, A., Dai, E., Liu, L. Y., \& Nation, P. N. (1998). Atherosclerosis in Marek's disease virus infected hypercholesterolemic roosters is reduced by HMGCoA reductase and ACE inhibitor therapy. Cardiovasc Res, 38(1), 237-246.

[21] Motorna, N. V., Rybalko, S. L. Starosyla, D. B., Guzyk, M. M., Strokina, I. G., Kaminsky, R. F. ... Chaikovsky, Y.B. (2018). The study of leukocyte phagocytic activity in the presence of herpetic infection and stroke. Wiadomosci Lekarskie, 71, 1, II, 155-159.

[22] Ooigawa, H., Nawashiro, H., Fukui, S., Otani, N., Osumi, A., Toyooka, T., \& Shima, K. (2006). The fate of Nissl-stained dark neurons following traumatic brain injury in rats: difference between neocortex and hippocampus regarding survival rate. 
Acta Neuropathol, 112(4), 471-481.

[23] Shi, Y., \& Tokunaga, O. (2002). Herpesvirus (HSV-1, EBV and $\mathrm{CMV}$ ) infections in atherosclerotic compared with nonatherosclerotic aortic tissue. Pathology International, 52(1), 31-39.

[24] Sorlie, P. D., Nieto, F. J., Adam, E., Folsom, A. R., Shahar, E., \& Massing, M. (2000). A prospective study of cytomegalovirus, herpes simplex virus 1 , and coronary heart disease: the atherosclerosis risk in communities (ARIC) study. Arch. Intern. Med., 160(13), 2027-2032.

[25] Sorrentino, R., Yilmaz, A., Schubert, K., Crother, T. R., Pinto, A., Shimada, K. ... Chen, S. (2015). A single infection with Chlamydia pneumoniae is sufficient to exacerbate atherosclerosis in ApoE deficient mice. Cellular immunology, 294(1), 25-32.

[26] Speetzen, L. J., Endres, M., \& Kunz, A. (2013). Bilateral common carotid artery occlusion as an adequate preconditioning stimulus to induce early ischemic tolerance to focal cerebral ischemia. Journal of visualized experiments: JoVE, (75), e4387.

[27] Thong-asa, W., \& Tilokskulchai, K. (2014). Neuronal damage of the dorsal hippocampus induced by long-term right common carotid artery occlusion in rats. Iranian Journal of Basic Medical Sciences, 17(3), 220-226.

[28] Turchyna, N. S., \& Savosko, S. I. (2018). The study of the initial stages of atherogenesis against high-fat diet. Physiological Journal, 64(2), 54-64.

[29] Wu, Y. P., Sun, D. D., Wang, Y., Liu, W., \& Yang, J. (2016). Herpes Simplex Virus Type 1 and Type 2 Infection Increases Atherosclerosis Risk: Evidence Based on a Meta-Analysis. BioMed research international, 2016, 2630865.

[30] Yao, H. W., Ling, P., Tung, Y. Y., Hsu, S. M., \& Chen, S. H. (2014). In vivo reactivation of latent herpes simplex virus 1 in mice can occur in the brain before occurring in the trigeminal ganglion. Journal of Virology, 88(19), 11264-11270. DOI: 10.1128/JVI.01616-14

[31] Yoshizaki K, Adachi K, Kataoka S, Watanabe A, Tabira T, Takahashi K, \& Wakita H. (2008). Chronic cerebral hypoperfusion induced by right unilateral common carotid artery occlusion causes delayed white matter lesions and cognitive impairment in adult mice. Exp. Neurol., 210(2), 585-591.

\section{ПАТОЛОГІЧНІ ЗМІНИ ГОЛОВНОГО МОЗКУ МИШЕЙ НА ТЛІ МОДЕЛЮВАННЯ ІШЕМІЇ 3 АСОЦІЙОВАНОЮ ВІРУСНОЮ ІНФЕКЦІЄЮ \\ Турчина Н.С., Савосько С.І., Рибалко С.Л., Старосила Д.Б., Колісник Д.І.}

У світовій літературі постійно зростає кількість даних, що свідчать про деякі інфекційні збудники, як чинників розвитку атеросклерозу та гострої цереброваскулярної патології, та про предиктори гострої серцево-судинної патології, як маркерів запалення. Неоднозначні результати досліджень взаємозв'язку між інфекцією $і$ атеросклерозом та намагання довести існування такого взаємозв'язку обумовили спроби змоделювати інфекція-асоційованого атерогенезу на тваринах. Зв'язок цих даних з ішемічним пошкодженням мозку ще мало досліджений, хоча в окремих експериментальних роботах доведено прогресуючу дегенерацію при крововиливі у мозок мишей, заражених вірусом простого герпесу 1 типу (ВПГ1), що пояснюється пост-інсультною імуносупресією та реактивацією інфрекційного агенту. Мета роботи - дослідити в експерименті можливий зв'язок між герпетичною інфрекцією та ішемічним пошкодженням кори головного мозку мишей. Для досягнення поставленої мети нами було сфрормовано 5 груп експериментальних тварин (мишей): 1 група ( $n=52)$, в дієті використовували холестерин; 2 група ( $n=23)$, із зараженням ВПГ1; 3 група ( $n=30)$, з однобічною оклюзією загальної сонної артерії (ОЗСА); 4 група ( $n=10)$, із зараженням ВПГ1 та ОЗСА; 5 група $(n=6)$, із зараженням ВПГ1, використанням холестеринової дієти та ОЗСА. Морфометрично на виготовлених мікропрепаратах оцінювали зміни щільності нейронів неокортексу тім'яної, скроневої ділянок мозку та гіпокампу. Статистичну обробку результатів проводили із застосуванням програми Origin Lab, версія 8.0. Встановлене вірогідне збільшення структурних змін у 5 групі (з трьома патологічними чинниками) комбінованої моделі порівняно з моделями без поєднання та/або з поєднанням декількох патологічних ознак 1, 2, 3 та 4 груп. Порівняння результатів між 1-4 та 5 групами, свідчить про статистично значуще збільщення відносної кількості нейронів 3 цитопатологічними ознаками (гіперхроматоз, деформація перикаріону, каріопікноз), яке корелює з більшою кількістю патологічних ознак, та вірогідно призводить до більш стрімкого пошкодження пірамідних нейронів неокортексу. Таким чином, редукція щільності пірамідних нейронів у тім'яній та/або скроневій корі мозку при комбінованій моделі з ішемізацією та вірусною асоціацією в експерименті була вірогідно більшою порівняно з моделями, у формуванні яких застосований лише один фрактор ризику. Виявлене збільшення ступені пошкодження неокортексу при ішемізації головного мозку у мишей із герпетичною інфекцією є свідченням можливого зв'язку між ними.

Ключові слова: головний мозок, миші, ішемія, вірусна інфекція.

\section{ПАТОЛОГИЧЕСКИЕ ИЗМЕНЕНИЯ ГОЛОВНОГО МОЗГА МЫШЕЙ НА ФОНЕ МОДЕЛИРОВАНИЯ ИШЕМИИ С АССОЦИИРОВАННОЙ ВИРУСНОЙ ИНФЕКЦИЕЙ \\ Турчина Н.С., Савосько С.И., Рыбалко С.Л., Старосила Д.Б., Колесник Д.И.}

В мировой литературе постоянно растёт количество данных, которые свидетельствуют о некоторых инфекционных возбудителях, как факторах развития атеросклероза и острой цереброваскулярной патологии, и о предикторах острой сердечно-сосудистой патологии, как маркеров воспаления. Неоднозначны результаты исследований взаимосвязи между инфекцией и атеросклерозом, а намерения доказать существование такой взаимосвязи обусловили попытки смоделировать инфекция-ассоциированный атерогенез на животных. Связь этих данных с ишемическим поражением мозга ещё мало исследована, хотя в отдельных экспериментальных работах доказана прогрессирующая дегенерация при кровоизлиянии в мозг мышей, зараженных вирусом простого герпеса 1 типа (ВПГ1), что объясняется пост-инсультной иммуносупрессией и реактивацией инфекционного агента. Цель работы - исследовать в эксперименте возможную связь между герпетической инфекцией и ишемическим поражением коры головного мозга мышей. Для достижения поставленной цели нами было сформировано 5 групп экспериментальных животных (мышей): 1 группа (n=52), в диете которой использовали холестерин, 2 группа (n=23) с заражением ВПГ1, 3 группа (n=30) с односторонней окклюзией общей сонной артерии (ООСА), 4 группа 
(n=10) с заражением ВПГ1 и ООСА, 5 группа (n=6) с заражением ВПГ1, использованием холестериновой диеты и ООСА. По микропрепаратам морфометрически оценивали изменения плотности нейронов неокортекса темянной, височной областей мозга и гиппокампа. Статистическую обработку результатов проводили с использованием программы Origin Lab, версия 8.0. Установлено достоверное увеличение структурных изменений в 5 группе (с тремя патологическими факторами) комбинированной модели по сравнению с моделями без объединения и/или с объединением нескольких патологических признаков 1, 2, 3 и 4 групп. Сравнение результатов между 1-4 и 5 группами свидетельствует о статистически значимом увеличении относительного количества нейронов с цитопатологическими признаками (гиперхроматоз, деформация перикариона, кариопикноз), которое коррелирует с большим количеством патологических признаков, и достоверно приводит к более стремительному поражению пирамидных нейронов неокортекса. Таким образом, редукция плотности пирамидных нейронов в теменной и/или височной коре мозга при комбинированной модели с ишемизацией и вирусной ассоциацией в эксперименте, была достоверно большей по сравнению с моделями, в фрормировании которых использован только один фрактор риска. Выявленное увеличение степени порожения неокортекса при ишемизации головного мозга у мышей с герпетической инфрекцией является свидетельством возможной связи между ними.

Ключевые слова: головной мозг, мыши, ишемия, вирусная инфекция. 